\title{
Penerapan Model Evaluasi CIPPO dalam Mengevaluasi Penyelenggaraan Lembaga PAUD
}

\author{
Felayati ${ }^{\circledR}{ }^{\circledR}$, Yaswinda ${ }^{2}$ \\ Pendidikan Anak Usia Dini, Universitas Negeri Padang \\ DOI: $10.31004 /$ obsesi.v4i1.238
}

\begin{abstract}
Abstrak
Penelitian ini bertujuan untuk mengevaluasi implementasi peraturan menteri No. 137 tahun 2014 tentang dan No. 146 tahun 2014 tentang kurikulum pendidikan anak usia dini di Kelurahan Air Tawar Barat Kota Padang. Subjek penelitian adalah lembaga PAUD di Kelurahan Air Tawar Barat Kota Padang. Metode yang digunakan dalam penelitian ini menggunakan evaluasi CIPPO dan tipe penelitian deskriptif. Informan penelitian yakni kepala sekolah sebagai informan utama, serta bagian tenaga administrasi sebagai informan triangulasi. Teknik pengumpulan data penelitian adalah wawancara, observasi, dan analisis dokumen. Hasil penelitian menunjukkan bahwa, implementasi Permendikbud No. 146 Tahun 2014 telah terlaksana dan Permendikbud No.137 Tahun 2014 secara keseluruhan belum terpenuhi secara optimal, seperti terdapat pada pengadaan sarana prasarana sekolah yang tidak terpenuhi, tidak memadai, dan tidak aman di digunakan oleh anak usia ini. Evaluasi CIPPO digunakan sebagai pengoptimalan kelemahan dari penerapan permendikbud No. 137 tahun 2014 pada beberapa lembaga PAUD di Kelurahan Air Tawar Barat Kota Padang.
\end{abstract}

Kata Kunci: kebijakan; pendidikan usia dini; model evaluasi CIPPO

\begin{abstract}
This study aims to evaluate the implementation of ministerial regulation no. 137 of 2014 about and No. 146 of 2014 concerning early childhood education curriculum in Air Tawar Barat Village, Padang City. The subjects of the study were PAUD institutions in Air Tawar Barat Kelurahan, Padang City. The method used in this study uses CIPPO evaluation and descriptive research types. Research informants namely the school principal as the main informant, and the administrative staff as the triangulation informant. Research data collection techniques are interviews, observation, and document analysis. The results showed that, the implementation of Permendikbud No. 146 of 2014 has been implemented and Permendikbud No.137 of 2014 as a whole has not been fulfilled optimally, such as in the provision of school infrastructure which is not fulfilled, inadequate, and unsafe for use by children at this age. CIPPO evaluation is used as an optimization of the weaknesses of the application of Permendikbud No. 137 of 2014 at a number of PAUD institutions in Air Tawar Barat Kelurahan, Padang City.
\end{abstract}

Keywords: policy; early childhood education; CIPPO evaluation model

Copyright (c) 2019 Felayati, Yaswinda

$\triangle$ Corresponding author :

Email Address : felayati64@gmail.com (Padang, Sumatera Barat)

Received 17 July 2019, Accepted 8 September 2019, Published 13 September 2019 


\section{PENDAHULUAN}

Salah satu tujuan negara Indonesia dinyatakan dalam Pembukaan Undang-Undang Dasar 1945 pada alinea ke 3 (tiga) adalah untuk mencerdaskan kehidupan bangsa. Maka setiap warga Negara Republik Indonesia berhak memperoleh akses dan kesempatan pendidikan yang merata, bermutu dan relevan, serta berdaya saing sesuai dengan minat, bakat serta kemampuan yang dimiliki setiap warga negara tanpa memandang status sosial, etnis dan gender di seluruh pelosok tanah air. Dimulai dari pendidikan dasar hingga perguruan tinggi, pendidikan formal dan non formal harus terlaksana dengan merata di Indonesia.

Menurut (Yaswinda, 2017; Yaswinda, Yulsyofriend, \& Mayar, 2018) pendidikan anak ketika usia dini merupakan dasar demi terbentuknya kepribadian seorang individu secara utuh, yakni dengan munculnya karakter, budi pekerti, kepandaian serta keterampilan. Pada masa inilah, anak memasuki masa keemasan atau golden age. (Fadlillah, M \& Lilif, 2013) menyebutkan bahwa, pada masa keemasan atau golden age terjadi transformasi yang luar biasa pada otak dan fisik anak. The golden age yaitu masa ketika anak mempunyai banyak potensi yang sangat baik untuk dikembangkan. Pada tahap ini, menjadi waktu yang sangat tepat untuk menanamkan nilai-nilai kebaikan karakter yang nantinya diharapkan akan membentuk kepribadiannya.

Nilai karakter perlu ditumbuh kembangkan melalui pendidikan, benih-benih individualitas yang sangat berharga itu yang memungkinkan terbentuknya suatu kepribadian unik akan tetap tinggal laten (Suryana, 2013). Dengan kata lain, kepribadian seseorang tidak akan terbentuk dengan semestinya sehingga seseorang tidak memiliki warna kepribadian yang khas sebagai milikinya. Dampak dari tidak terstimulasinya berbagai potensi saat usia emas, akan menghambat tahap perkembangan anak berikutnya. Jadi, usia emas hanya sekali dan tidak dapat diulang lagi (Suryana, 2014a).

Disamping itu Academic success adalah tujuan utama berbagai kebijakan sekolah efektif yang menerapkan academic press dalam iklim belajarnya, yang disisi lain juga mengusahakan pembangunan iklim sosial- emosional lewat hubungan yang hangat antara siswa dengan teman sebaya dan orang dewasa disekolah. (Ayuningtyas, Hartati, \& Sumadi, 2019)

Pendidikan anak usia dini merupakan aset dasar sekaligus aspek terpenting dalam membentuk generasi Indonesia yang berkualitas, beriman dan bertaqwa. Untuk itu diperlukan panduan dan acuan penyelenggaraan sebuah lembaga PAUD dengan diterbitkannya peraturan menteri no. 146 tahun 2014 tentang kurikulum dan peraturan menteri no. 137 tahun 2014 tentang standar pendidikan nasional PAUD.

Namun pelaksanaan peraturan menteri tentang standar nasional pendidikan dan kurikulum PAUD yang telah dibuat tidak dapat terlaksana dengan optimal. Banyak lembaga PAUD yang berdiri namun kelayakan sarana prasarana tidak memadai. Adapun lembaga yang berdiri hampir di setiap kelurahan belum memenuhi kriteria sarana prasarana pada peraturan menteri no. 137 tahun 2014, seperti luas tanah, kelengkapan gedung atau ruang belajar, alat permainan dan kondisi yang kondusif.

Pada umumnya pendirian lembaga PAUD ialah milik yayasan yang didirikan dibagian rumah pemilik yayasan. Ruang untuk belajar dan rumah pemilik sebagian besar di sekat untuk ruang belajar PAUD. Permainan yang disediakan hanyalah sebagian kecil dari yang diharapkan untuk permainan PAUD, seperti permainan balok, permainan kendaraan, alat musik yang sudah lama, dan permainan tidak aman untuk anak bahkan permainan yang disediakan di kelas juga tergolong sudah usang. Serta penyediaan jamban dan uks yang tidak maksimal. Sebagian lembaga menyediakan jamban, namun jamban yang disediakan tidak kondisuf untuk pertumbuhan anak, jamban yang tersedia masih tergolong sangat minim, yakni hanya ada 1 jamban dan kebersihan juga tidak terjaga. Sedangkan uks PAUD hanya ada beberapa lembaga yang menyediakan, dan bahkan hanya menggunakan poster uks tetapi tidak dilengkapi dengan alat-alat uks dan ruang uks. 
Untuk mewujudkan pendidikan anak usia dini yang layak dan mendukung stimulasi pertumbuhan dan perkembangan anak usia dini maka dikeluarkan kebijakan yang mengatur tentang sistem penyelenggaraan pendidikan sebagaimana terakhir dikeluarkan Undang-Undang Nomor 20 Tahun 2003 tentang Sistem Pendidikan Nasional pasal 1 ayat 14 dinyatakan bahwa Pendidikan Anak Usia dini (PAUD) adalah suatu upaya pembinaan yang ditujukan kepada anak sejak lahir sampai usia enam (0-6 tahun) yang dilakukan melalui pemberian rangsangan pendidikan untuk membantu pertumbuhan dan perkembangan jasmani dan rohani agar anak memiliki kesiapan dalam memasuki pendidikan lebih lanjut. Demi mewujudkan generasi yang berkualitas, pemerintah juga harus berperan serta sebagaimana telah di atuar oleh Undang-Undang Nomor 20 Tahun 2003 pasal 11 ayat 1 juga mengamanatkan kepada pemerintah pusat dan pemerintah daerah, agar menjamin terselenggaranya pendidikan yang bermutu bagi setiap warganya (Roberts, 2003).

Menurut Rossi, et all (dalam (Ambiyar, Yulastri, Putri, \& Wulansari, 2018) : "Evaluation research is the systematic application of social research proce dures in assessing the conceptualization and design, implementation, and utility of social intervention programs". Berdasarkan definisi tersebut, penelitian evaluasi adalah aplikasi secara sistematis dari prosedur-prosedur penelitian sosial yang dapat menilai konsep dan rancangan, pelaksanaan, serta kegunaan dari program intervensi sosial. Tujuan evaluasi menurut (Lastuti \& Jaedun, 2014) yaitu untuk melakukan perbaikan penggunaan sumberdaya organisasi. Sedangkan tujuan penelitian evaluasi adalah untuk mengukur dampak dari sebuah program sebagai landasan dalam pengambilan keputusan dan untuk memperbaiki program selanjutnya. Model CIPPO yang dimodifikasi dari model CIPP terdiri dari context, input, process, product dan outcome.

Penelitian yang dilakukan oleh (Tamaya, 2017) menggunakan evaluasi model CIPP menunjukkan bahwa, implementasi standar sarana prasarana PAUD, dikaji berdasarkan Permendikbud No. 137 Tahun 2014 pada lembaga PAUD di kecamatan Gunungpati, secara keseluruhan implementasi belum terpenuhi secara optimal. Beberapa standar yang belum dapat tepenuhi, yaitu adanya 3 lembaga belum memenuhi rasio gerak anak minimal $3 \mathrm{~m} 2,2$ lembaga belum memiliki ruang UKS secara khusus, dan 1 lembaga belum mencapai standar minimal pada luas lahan yang dimiliki. Lebih lanjut penelitian (Hartati, 2017) menunjukkan hasil bahwa penyelanggaraan program PAUD di Jakarta Timur yang di evaluasi menggunakan model CIPP menunjukkan bahwa secara evaluasi konteks sudah memiliki izin operasional, evaluasi input pengelompokkan usia anak dan pembuatan kurikulum menggunakan tulisan tangan. Evaluasi proses, terkait dengan pelaksaan jam pembelajaran dan jadwal pendidik yang belum terencana dengan baik. Evaluasi produk, guru memberikan rapor sebagai bentuk laporan perkembangan anak.

Penelitian terdahulu telah mengkaji tentang implementasi permen no. 137 tahun 2014 di lembaga PAUD. Namun pada penelitian terdahulu belum menggunakan model evaluasi CIPPO yang memudahkan peneliti dalam melakukan evaluasi implementasi suatu program dengan komponen outcome atau hasil. Program Pendidikan Anak Usia Dini (PAUD) telah terlaksana hampir merata disetiap provinsi dan daerah. Data PAUD dari tahun ketahun juga terus menunjukkan angka peningkatan. Sutomo, (2014) menjelaskan, bahwa terdapat tujuh komponen sekolah yang harus dikelola dengan baik, yaitu memiliki kurikulum, program pengajaran, tenaga kependidikan, kesiswaan, sarana prasarana pendidikan pengelolaan hubungan sekolah dan masyarakat serta manajemen pelayanan khusus lembaga pendidikan.

Selain komponen-komponen pendidikan, terdapat juga standar pendidikan dan kurikulum. Standar pendidikan anak usia dini merupakan acuan minimal dalam penyelenggaraan program PAUD, baik jalur pendidikan formal, nonformal ataupun informal yang diatur dalam bentuk Peraturan Menteri Pendidikan dan Kebudayaan RI Nomor 137 Tahun 2013 (Pendidikan, Kebudayaan, \& Indonesia, 2014). Dan kurukulum digunakan sebagai pedoman penyelenggaraan kegiatan pembelajaran untuk mencapai 
DOI: $10.31004 /$ obsesi.v4i1.238

tujuan pendidikan tertentu, yang diatur dalam Peraturan Menteri Pendidikan dan Kebudayaan RI Nomor 146 Tahun 2013 (Kemendikbud, 2015).

Kurikulum sebagai kerangka terorganisir yang menggambarkan isi, proses pembelajaran untuk membantu anak-anak mencapai tujuan kurikulum, apa yang guru lakukan untuk membantu anak-anak mencapai tujuan, dan konteks di mana pengajaran dan pembelajaran terjadi. Dalam struktur kurikulum 2013 PAUD hasil belajar anak dituangkan ke dalam kompetensi inti sikap, pengetahuan, dan keterampilan. Proses pembelajaran ditujukan untuk mengembangkan sikap, pengetahuan, dan keterampilan (Suryana, Dadan \& Fitri, 2018) .

Lebih lanjut (Suryana, 2014b) mengemukakan bahwa pola pendidikan yang bersifat demokratis dipandang cocok untuk mendorong tumbuh dan berkembangnya potensi individu. Hal ini sesuai dengan prinsip kurikulum 2013 yang mengarahkan pada pembeljaran berpusat pada anak. Dalam pengembangan individualitas melalui pendidikan tidak dibenarkan jika pendidik memaksakan keinginannya kepada subjek didik. Tugas pendidik hanya menunjukkan jalan dan mendorong subjek didik bagaimana cara memperoleh sesuatu dalam mengembangkan diri dengan berpedoman pada prinsip yang dikemukakan oleh Dewantoro yakni ing ngarso sungfulodo, ing madyanrangun karso, fuf wuri handayani.

Berdasarkan latar belakang yang telah dipaparkan penulis ingin mengetahui secara lebih mendalam tentang implementasi Peraturan Menteri Pendidikan dan Kebudayaan RI Nomor 137 Tahun 2014 dan 146 Tahun 2014 pada Pendidikan Anak Usia Dini yang ada di Kelurahan Air Tawar Barat Kota Padang.

\section{METODOLOGI}

Penelitian dilaksanakan di Lembaga PAUD Kelurahan Air Tawar Barat Kota Padang yang berjumlah delapan (8) Lembaga PAUD di Kelurahan Air Tawar Barat. Provinsi Sumatra Barat. Objek penelitian adalah lembaga, guru dan orang tua anak didik. Metode yang digunakan adalah penelitian kualitatif dengan Model Evaluasi CIPPO (Context, Input, Process, Product, Dam Outcome). Teknik pengumpulan data dilakukan dengan observasi, wawancara dan dokumentasi. Alat observasi yang digunakan berbentuk catatan lapangan, wawancara dilakukan pada kepala sekolah dan orang tua anak didik. Data dokumentasi berupa foto sebagai lampiran untuk memperkuatkan hasil penelitian. Data dianalisis dengan menggunakan analisis model evaluasi CIPPO.

\section{HASIL DAN PEMBAHASAN}

Analisis implementasi ditinjau dengan evaluasi CIPPO meliputi context, input, process, product dan outcome. Berdasarkan Context Evaluation Standar nasional PAUD dan Kurikulum 2013 PAUD menjadi sebuah acuan yang harus diikuti oleh semua lembaga PAUD untuk terlaksananya pendidikan anak usia dini yang optimal. Sebagaimana menurut Brown (dalam Anamara, 2014) menyebutkan bahwa standar PAUD, diharapkan mampu menjadi standar acuan minimal bagi masyarakat dan stakeholder untuk memberikan pelayanan pendidikan yang berkualitas bagi anak usia dini. Hal ini dikarenakan, standar PAUD menjadi bagian integral dari Standar Nasional Pendidikan, sebagaimana diamanatkan dalam Permendikbud No. 137 Tahun 2014, tentang Standar Nasional Pendidikan Anak Usia Dini.

Standar PAUD terdiri atas delapan standar, diantaranya yakni: standar tingkat pencapaian perkembangan, standar isi, standar proses, standar penilaian,standar pendidik dan standar tenaga kependidikan, standar sarana dan prasarana,standar pengelolaan, serta standar pembiayaan. Standar PAUD merupakan satu kesatuan yang tidak terpisahkan dalam pengelolaan dan penyelenggaraan pendidikan anak usia dini (Bab 2 Pasal 2). Selanjutnya Standar PAUD sebagaimana dimaksud pada ayat (1) menjadi acuan dalam pengembangan, implementasi, dan evaluasi kurikulum PAUD (Bab 2 Pasal 2). 
Sedangkan kurikulum 2013 pendidikan anak usia dini menurut Undang-Undang Nomor 20 tahun 2003 tentang Sistem Pendidikan Nasional Bab I Pasal I poin 19 adalah seperangkat rencana dan pengaturan mengenai tujuan, isi dan bahan pelajaran serta cara yang digunakan sebagai pedoman penyelenggaraan kegiatan pembelajaran untuk mencapai tujuan pendidikan tertentu.

Di dalam lampiran peraturan menteri pendidikan dan kebudayaan (permendikbud) No. 146 tahun 2014 tentang Pedoman Pengembangan Kurikulum Tingkat Satuan Pendidikan dinyatakan bahwa Kurikulum Tingkat Satuan Pendidikan (KTSP) untuk PAUD adalah kurikulum operasional yang dikembangkan dan dilaksanakan sesuai dengan karakteristik satuan PAUD (Pendidikan, 2016). Merujuk pada ketentuan tersebut di atas, maka Kurikulum Tingkat Satuan Pendidikan (KTSP) merupakan keharusan yang disusun oleh dan dilaksanakan di satuan pendidikan masing-masing.

Dapat diketahui dari 8 sekolah PAUD yang ada di Kelurahan Air Tawar Barat Padang menggunakan Standar PAUD dalam pengelolaan dan penyelenggaran pendidikan anak usia dini dan menggunakan kurikulum 2013 sebagai acuan pembelajaran. Standar PAUD juga telah dijadikan acuan sekolah PAUD/TK dalam pengembangan, implementasi, dan evaluasi kurikulum PAUD. Standar PAUD telah berfungsi sebagimana mestinya yang dimaksud oleh Pasal 3, yakni berfungsi sebagai dasar dalam perencanaan, pelaksanaan, pengawasan, dan tindak lanjut pendidikan dalam rangka mewujudkan PAUD bermutu; acuan setiap satuan dan program PAUD untuk mewujudkan tujuan pendidikan nasional; dan dasar penjaminan mutu PAUD. Hal ini telah terlaksana sesuai dengan fungsi Standar PAUD yang dibuat oleh Permendikbud No. 137 Tahun 2014.

Sedangkan kurikulum digunakan sebagai pedoman pembelajaran yang meliputi muatan kurikulum, kompetensi inti, kompetensi dasar, dan lama belajar yang harus dikembangkan dan diterapkan di lembaga PAUD di Kelurahan Air Tawar Barat Kota Padang. Kurikulum 2013 mengusung pengembangan pembelajaran konstruktivisme yang lebih bersifat fleksibel dalam pelaksanaan sehingga memberi ruang pada anak untuk mengembangkan potensi dan bakatnya (Suryana, Dadan \& Fitri, 2018).

Karakteristik kurikulum 2013 pendidikan anak usia dini dirancang dengan karakteristik mengoptimalkan perkembangan anak yang meliputi 6 aspek perkembangan, menggunakan pembelajaran tematik dengan pendekatan saintifik dalam pemberian rangsangan pendidikan, dan menggunakan penilaian autentik dalam memantau perkembangan anak; dan memberdayakan peran orang tua dalam proses pembelajaran (Suryana, Dadan \& Fitri, 2018).

Standar nasional pendidikan anak usia dini dan kurikulum 2013 tidak dapat dipisahkan dari berdirinya suatu lembaga PAUD, karena selain standar nasional pendidikan untuk berdirinya suatu lembaga, kurikulum adalah syarat dari berjalannya suatu proses pembeljaran untuk sebuah pendidikan.

Adapun hasil yang diporeleh dari analisis data observasi dan wawancara untuk komponen/evaluasi conteks, input, process, product dan outcome dari implementasi permendikbud no 137 tahun 2014 tentang standar nasional pendidikan anak usia dini dan permendikbud 146 tahun 2014 tentang kurikulum 2013 pendidikan anak usia dini ialah sebagai berikut:

\section{Conteks Evaluation (Evaluasi Konteks)}

Contect evaluation to serve planning desicion, konteks evaluasi ini membantu merencanakaan keputusan, menentukan kebutuhan yang akan dicapai oleh program dan merumuskan tujuan program (Arikunto, 2012). Evaluasi konteks adalah analisis kebutuhan (needs assesment). Pertanyaan dasar dalam komponen evaluasi yakni tentang "apa yang dibutuhkan?". Konteks penyelenggaraan kebijakan standar nasional pendidikan dan kurikulum, pertanyaan tersebut dapat dikembangkan menjadi "apa yang dibutuhkan oleh 
DOI: 10.31004/obsesi.v4i1.238

lembaga PAUD di Kelurahan Air Tawar Barat Kota Padang yang di evaluasi sesuai dengan isi Permendikbud No. 137 Tahun 2014 dan Permendikbud No. 146 Tahun 2014?".

Tujuan pokok dari evaluasi konteks ialah untuk mengetahui apakah penyelenggaraan kebijakan permendikbud No. 137 Tahun 2014 tentang standar pendidikan nasional dan Permendikbud No. 146 Tahun 2014 tentang kurikulum pendidikan anak usia dini memiliki landasan formal yang kuat serta apakah kebijakan tersebut dapat menelaah kelebihan dan kelemahan penyelenggaraan kebijakan tersebut di lembaga PAUD di Keluarahan Air Tawar Barat Kota Padang.

Landasan formal yang kuat tentang kebijakan standart nasional pendidikan anak usia dini ialah permendikbud no. 137 tahun 2014 dan untuk kurikulum ialah permendikbud no. 146 tahun 2014. Sehingga penyelenggaraan dan pengadaan lembaga PAUD harus terlaksana sesuai dengan acuan permendikbud tentang standar nasional pendidikan anak usia dini dan kurikulum pendidikan anak usia dini.

\section{Input Evaluation (Evaluasi Masukan)}

Evaluasi input yang dimaksudkan untuk membantu menentukan program guna melakukan perubahan-perubahan yang dibutuhkan (Mahmudi, 2011). Evaluasi input mencari hambatan dan potensi sumber daya yang tersedia dalam suatu lembaga.

Hasil observasi dan wawancara (Tanggal 14-16 Mei 2019) dengan delapan kepala sekolah atau guru lembaga PAUD Kelurahan Air Tawar Barat yakni sebagai berikut:

Sumber daya manusia Dan KTSP

Tabel. 1.1. SDM dalam permen 137 tahun 2014 dan Pihak Penyusun KTSP di Keluarahan Air Tawar Barat

\begin{tabular}{|c|c|c|}
\hline \multicolumn{3}{|c|}{ SDM dalam Permen No. 137 Tahun 2014} \\
\hline Observasi & Wawancara & Simpulan \\
\hline $\begin{array}{l}\text { Guru dalam } 1 \\
\text { lembaga PAUD pada } \\
\text { umumnya terdiri } \\
\text { dari } 3 \text { orang guru }\end{array}$ & $\begin{array}{l}\text { Dalam } 1 \text { sekolah PAUD ada } 3 \\
\text { guru terdiri dari: } 1 \text { kepala } \\
\text { sekolah, } 2 \text { guru kelas dan } \\
\text { merangkap sebagai } \\
\text { operator/TU. } \\
\text { Peserta didik rata-rata 15-20 } \\
\text { orang. }\end{array}$ & $\begin{array}{l}\text { Tenaga kependidikan di PAUD di } \\
\text { Kelurahan Air Tawar Barat sudah cukup } \\
\text { memenuhi tujuan dari Pasal 24, adanya } \\
\text { guru PAUD, guru pendamping dan } \\
\text { pendamping muda. Walaupun guru } \\
\text { masih bertugas merangkap sebagai } \\
\text { administrasi dan pelayanan teknis. }\end{array}$ \\
\hline SDM guru secara & Dari 8 PAUD di Kelurahan Air & SDM dari segi kualitas dan kuantitas telah \\
\hline kualitas masih & Tawar Barat di ketahui SDM & mencukupi, namun masih terdapat \\
\hline kurang mencukupi. & untuk pengelola dan pendidik & pendidik PAUD tamatan SMA dari 8 \\
\hline Kualifikasi guru & telah cukup dari segi kualitas & lembaga PAUD terdapat 3 lembaga PAUD \\
\hline masih banyak yang & dan kuantitas, rata-rata setiap & yang memberdayakan tamatan SMA \\
\hline bukan berasal dari & lembaga PAUD memiliki & untuk menjadi pendidik PAUD. \\
\hline latar belakang & lulusan Sarjana/Sarjana & Meskipun ada beberapa tamatan SMA \\
\hline pendidikan & PGPAUD. & yang menjadi Guru telah mengikuti \\
\hline PAUD/Psikologi & & \\
\hline
\end{tabular}

Tabel. 1.2. Sumber Daya Manusia Dalam Permen No. 146 Tahun 2014

Pihak yang terlibat dalam pengembangan KTSP dalam Permen No. 146 Tahun 2014

\begin{tabular}{|c|c|c|}
\hline Observasi & Wawancara & Simpulan \\
\hline $\begin{array}{llr}\text { KTSP telah di } & \text { susun oleh } \\
\text { pendidik } & \text { dan } & \text { tenaga } \\
\text { kependidikan } & & \text { lemabaga } \\
\text { PAUD } & & \end{array}$ & $\begin{array}{l}\text { Di satu lemabaga PAUD kepala } \\
\text { sekolah, guru dan tenaga } \\
\text { administrasi sekolah bersama- } \\
\text { sama melakukan penyusunan } \\
\text { KTSP }\end{array}$ & $\begin{array}{l}\text { Penyusunan KTSP dilakukan } \\
\text { secara bersama oleh tenaga } \\
\text { kependidikan dalam } 1 \text { lembaga } \\
\text { PAUD. }\end{array}$ \\
\hline
\end{tabular}

Hasil telaah dokumen, observasi dan wawancara sumber daya manusia di lembaga PAUD di Kelurahan Air Tawar Barat Kota Padang dapat di ketahui bahwa pengelolaan tenaga pendidik masih merangkap sebagi guru dan tenaga administrasi. Kualifikasi 
DOI: $10.31004 /$ obsesi.v4i1.238

pendidikan masih terdapat yang tamatan SMA untuk menjadi pendidik Taman KanakKanak (TK) dan PAUD. Perlunya pembagian tugas bahwa tugas guru adalah mengajar dan mendidik dan tenaga administrasi mengelola administrasi. Untuk SDM yang terlibat dalam penyusunan KTSP ialah semua tenaga pendidik dan kependidikan di lembaga PAUD. Hal ini dilakukan agar penyusunan KTSP dapat berjalan dengan lancar.

Faktor-faktor yang mempengaruhi kegiatan proses sistem pembelajaran menurut Wina Sanjaya (2009 dalam (Lastuti \& Jaedun, 2014) yakni: faktor guru, peserta didik, sarana pra sarana dan faktor lingkungan. Semua komponen sumberdaya tersebut menjadi pilar kemajuan suatu lembaga PAUD.

\section{Biaya}

Tabel 1.3. Biaya Operasional dan Biaya Personal PAUD di Kelurahan Air Tawar Kota Padang Biaya dalam Permen No. 137 Tahun 2014

\begin{tabular}{|c|c|c|}
\hline \multicolumn{3}{|c|}{ Biaya dalam Permen No. 137 Tahun 2014} \\
\hline Observasi & Wawancara & Simpulan \\
\hline PAUD di Kelurahan Air & Pembiayaan untuk & Biaya operasional PAUD di Keluarahan Air \\
\hline Tawar ada PAUD swasta, & sarana prasarana di & Tawar terlihat berbeda-beda, karen ada \\
\hline yang mana biaya & dapat dari BOP dan & beberapa sekolah yang sarana \\
\hline operasional berasal dari & Bantuan APE & prasarananya lengkap dan yang tidak, pada \\
\hline Yayasan atau dari BOP. & & umumnya biaya operasional di dapatkan \\
\hline & & dari BOP dan unag Yayasan. \\
\hline Untuk gaji guru juga & Gaji guru di peroleh & Lembaga Paud yang memiliki banyak \\
\hline $\begin{array}{l}\text { tergantung pada } \\
\text { murid PAUD }\end{array}$ & $\begin{array}{lll}\text { dari } & \text { SPP murid dan } \\
\text { dari } & \text { BOP atau dari }\end{array}$ & $\begin{array}{l}\text { murid akan mampu mensejahterakan guru, } \\
\text { dikarenakan gaii guru pada umumnva di }\end{array}$ \\
\hline & Yayasan & $\begin{array}{l}\text { peroleh dari SPP murid, uang yayasan dan } \\
\text { BOP. }\end{array}$ \\
\hline
\end{tabular}

Hasil telaah dokumen, observasi dan wawancara yang dilakukan penulis diketahui bahwa biaya operasional dan biaya personal di lembaga PAUD di Kelurahan Air Tawar Barat Kota Padang masih kurang mencukupi hal ini terlihat di eberapa lembaga PAUD masih sangat minim sarana prasarana permainan outdoor dan indoordan gaji guru yang belum merata antar lembaga di Kelurahan Air Tawar Barat. Untuk itu diharapkan kerjasama dan dukungan lintas sektoral serta pemanfaatan dana desa dan perlunya dukungan swadaya masyarakat

\section{Sarana dan Prasarana}

Tabel 1.4. Sarana dan prasarana PAUD di Kelurahan Air Tawar Barat Kota Padang

\section{Sarana dan Prasarana dalam Permen No. 137 Tahun 2014}

\begin{tabular}{|c|c|c|}
\hline Observasi & Wawancara & Simpulan \\
\hline Sarana prasarana PAUD di & Sarana prasarana PAUD di & - Sarana dan prasarana untuk \\
\hline Kelurahan Air Tawar Barat dari 8 & Kelurahan Air Tawar Barat & pelaksanaan PAUD di \\
\hline lembaga PAUD hanya 2 lembaga & Kota Padang secara & Kelurahan Air Tawar Barat \\
\hline yang masuk pada kategori. & menyeluruh belum sesuai & Kota Padang masih belum \\
\hline Sarana prasarana yang dimaksud & dengan prinsip pengadaan & layak dan kondisif untuk \\
\hline $\begin{array}{l}\text { oleh pasal } 31 \text { ayat } 3 \text { yakni, bersih, } \\
\text { aman, nyaman, indah, sesuai } \\
\text { tingkat perkembangan dan }\end{array}$ & $\begin{array}{l}\text { sarana dan prasarana, masih } \\
\text { ada beberapa PAUD yang } \\
\text { hanya memiliki } 1 \text { permainan }\end{array}$ & $\begin{array}{l}\text { digunakan oleh anak usia dini } \\
\text { dan belum lengkap. }\end{array}$ \\
\hline memanfaatkan potensi & outdoor, permainan iindoor & cana gedung yang belum \\
\hline lingkungan. Sedangkan 6 & & \\
\hline lembaga lainnya masih memiliki & ak dan kurang & \\
\hline $\begin{array}{l}\text { kelemahan seperti kurang bersih } \\
\text { dan tidak lengkapnya sarana } \\
\text { prasarana. }\end{array}$ & $\begin{array}{l}\text { bervariasi untuk } \\
\text { menstimulasi perkembangan } \\
\text { anak. }\end{array}$ & $\begin{array}{l}\text { - Sarana permainan yang masih } \\
\text { kurang lengkap }\end{array}$ \\
\hline
\end{tabular}


DOI: $10.31004 /$ obsesi.v4i1.238

Hasil telaah dokumen, observasi dan wawancara yang dilakukan penulis diketahui bahwa sarana dan prasarana lembaga PAUD di Kelurahan Air Tawar Barat Kota Padang belum lengkap, masih terdapat lembaga PAUD yang kekurangan sarana prasana yang memadai dari mulai gedung, jamban yang bersih, ruang uks, ruang guru, ruang kepala dan alat permainan edukatif. Untuk itu perlu solusi dan persyaratan yang ketat untuk menerima murid dan membuka lembaga PAUD, harus disesuaikan dengan kondisi sarana prasarana yang memadai. Diharapkan pada seluruh yang terlibat dalam pembangunan pendidikan dan pengawas pendidikan untuk menseleksi lembaga yang layak untuk membuka PAUD. Agar PAUD dapat berkualitas dan kuantitasnya terjamin dan layak untuk dilakukan proses belajar dan mengajar dengan kondusif.

\section{Process Evaluation (Evaluasi Proses)}

Evaluasi proses adalah pelaksanaan program. Pertanyaan mendasar yakni: “apakah program sedang dilaksanakan (it is being done)?". Evaluasi proses dapat meninjau kembali rencana organisasi dan evaluasi-evaluasi terdahulu untuk mengidentifikasi aspek-aspek penting dari organisasi yang harus dimonitor (Mahmudi, 2011). Di sini yang mesti diingat adalah bahwa evaluasi proses terutama bertujuan untuk memastikan prosesnya.

\section{Perencanaan, Pelaksanaan, Evaluasi dan Pengawasan Pembelajaran dan Penyusunan Perangkat Pembelajaran.}

Tabel 1.5. Perencanaan pembelajaran PAUD dalam permen 137

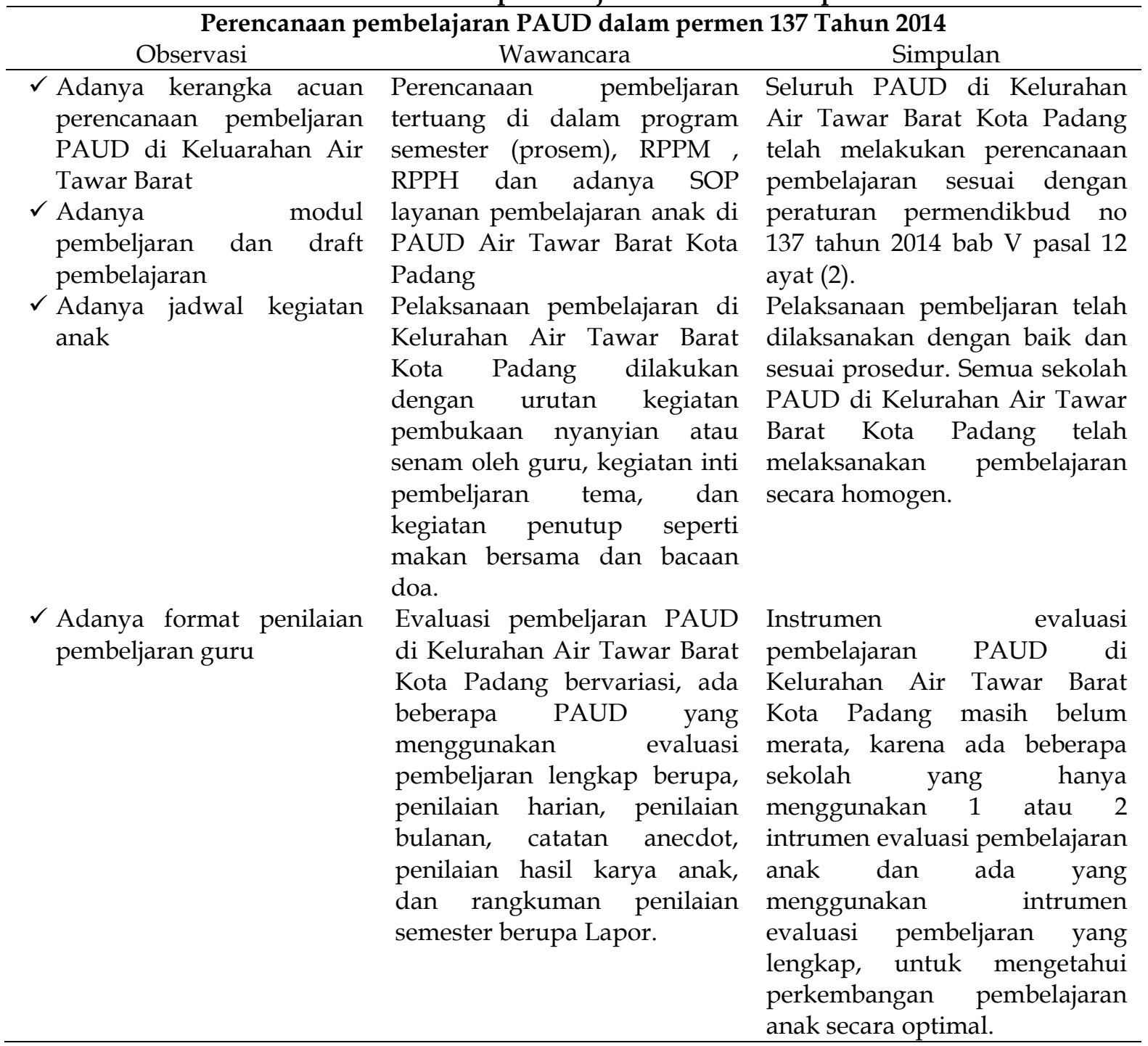


Perencanaan pembelajaran PAUD dalam permen 137 Tahun 2014 Observasi

Wawancara

Adanya pengawasan dari

dinas pendidikan atau yang

disebut dengan penilik, yang

datang 1 bulan sekali
Simpulan

Pengawasan pembelajaran yang dilakukan oleh pemerintah yakni dinas pendidikan telah terlaksana di PAUD Kelurahan Air Tawar Barat Kota Padang

Tabel. 1.6. Penyusunan Perangkat Pembelajaran Dalam Permen No. 146 Tahun 2014

Penyusunan Perangkat Pembeljaran dalam permen 146 Tahun 2014

Observasi

Wawancara

Simpulan

$\checkmark$ Adanya penyusunan Penyusunan perangkat pembeljaran Pelaksanaan penyusunan perangkat pembelajaran

dilakukan dalam bentuk kurikulum sekolah, yang meliputi Program perangkat pembelajaran

$\checkmark$ Penyusunan program

$\checkmark$ Pelaksanaan program

SemesterRencana

Pelaksanaan

di lembaga PAUD sudah

$\checkmark$ Tindak Lanjut

Pembelajaran Mingguan (RPPM),

Rencana Pelaksanaan Pembelajaran

terjalankan dengan baik

di Kelurahan Air Tawar

Harian (RPPH), Standar Operasional

Prosedur (SOP), Beban Belajar,

Ketuntasan Belajar, Alokasi Waktu,

Kalender Akademik

Hasil telaah dokumen, observasi dan wawancara yang dilakukan penulis diketahui bahwa perencanaan pembelajaran dan penyusunan perangkat pembeljaran PAUD di Kelurahan Air Tawar Barat Kota Padang dapat dilihat bahwa perencanaan sudah dilaksanakan diawal tahun yaitu menyusun peorgram semester, RPPM, dan RPPH dan telah dilaksanakan secara merata dan sama oleh PAUD di keluarahan Air Tawar Barat.

Evaluasi juga telah dilakukan oleh semua lembaga PAUD, walaupun masih ada instrumen evaluasi pembelajaran yang bervariasi, ada beberapa lembaga yang memiliki intrumen evaluasi lengkap dan ada yang masih kurang lengkap. Kemudian pengawasan pembelajaran PAUD oleh kepala satuan PAUD atau yang sering disebut sebagai penilik dari dinas pendidikan telah dilaksanakan secara berkala di Keluarahan keluarahan Air Tawar Barat Kota Padang. Sehingga proses pelaksanaan belajar dan mengajar di PAUD dapat terlaksana dengan efektif. Hanya saja masih diperlukan penyetaraan intrumen evaluasi pembelajaran PAUD di Keluarahan keluarahan Air Tawar Barat Kota Padang.

\section{Product Evaluation (Evaluasi Produk)}

Evaluasi produk adalah evaluasi yang bertujuan untuk mengukur, menginterpretasikan, dan menilai capaian program (Muyana, 2017). Selain itu, untuk menilai luaran atau outcome dan menghubungkan hal tersebut secara objektif dengan konteks, input, dan proses. Komponen produk atau hasil merupakan penilaian yang dilakukan untuk mengukur keberhasilan dalam pencapaian tujuan yang telah ditetapkan. Komponen produk pada proses pembelajaran PAUD di Kelurahan Air Tawar Barat berupa Standar Isi Tentang Tingkat Pencapaian Perkembangan Anak (STTPPA) dan pelaksanaan kurikulum 2013 yang telah dilaksanakan oleh lembaga PAUD.

Kegiatan proses pembelajaran di lembaga PAUD di Kelurahan Air Tawar Barat Kota Padang pada umumnya telah menggunakan STTPPA sebagai acuan. Sedangkan pada kurikulum yang telah dilaksanakan telah meliputi pelaksanaan pembelajaran berdasarkan program muatan kurikulum, kompetensi inti, kompetensi dasar dan lama belajar yang telah di susun dan dilaksanakan. Upaya pelaksanakan kurikulum 2013 dan pembelajaran menggunakan STTPPA telah terlaksana dengan baik di PAUD Keluarahan Air Tawar Barat Kota Padang. 
DOI: $10.31004 /$ obsesi.v4i1.238

\section{Outcome Evaluation (Evaluasi Hasil)}

Outcome evaluation digunakan untuk mengukur sejauhmana dampak dari pelaksanaan evaluasi program yang telah dilaksanakan (Arikunto, 2012). Adapun dampak dari pelaksanaan permendikbud no 137 tahun 2014 tentang standar nasional pendidikan anak usia dini dan pelaksanaan permendikbud no 146 tahun 2014 ialah lembaga PAUD dari tahun ke tahun dapat mengalami perubahan perbaikan kearah yang lebih baik, seperti lembaga PAUD di Air Tawar Barat sudah 4 lembaga yang terakreditasi dan 4 lembaga PAUD lainnya dalam tahap persiapan akreditasi.

Hal ini dapat terlaksana akibat adanya permen 137 tahun 2014 tentang standar nasional pendidikan anak usia dini dan permendikbud no 146 tahun 2014 tentang kurikulum 2013 pendidikan anak usia. Para pengelola PAUD memfokuskan target yang harus dicapai sesuai dengan aturan yang telah di tetapkan. Tujuan evaluasi pembelajaran adalah untuk mengetahui keefektifan dan efisiensi sistem pembelajaran, baik yang menyangkut tentang tujuan, materi, metode, media, sumber belajar, lingkungan maupun sistem penilaian itu sendiri.

\section{KESIMPULAN}

Hasil evaluasi model CIPPO terhadap implementasi Peraturan Menteri No.146 dan No. 137 tahun 2014 diperoleh gambaran bahwa peraturan tersebut sudah terlaksana namun belum optimal, utamanya pada bagian sarana prasarana pendidikan. Lembaga PAUD berupaya memperbaiki kelemahan dengan pengadaan sarana prasarana yang dibuktikan dengan sudah hampir 50\% lembaga PAUD di Kelurahan Air Tawar Barat Kota Padang telah terakreditasi meskipun akreditasi yang diperoleh masih dalam kategori cukup (C).

\section{UCAPAN TERIMAKASIH}

Terima kasih terutama kepada Bapak Dr. Dadan Suryana, M.Pd yang telah memberi bimbingan, Ibu Zulherma, S.Pd yang telah memberikan arahan penelitian, serta kepada editor dan reviewer Jurnal Obsesi : Jurnal Pendidikan Anak Usia Dini yang telah memberikan masukan dalam penulisan artikel ini.

\section{DAFTAR PUSTAKA}

Ambiyar, A., Yulastri, A., Putri, Y. E., \& Wulansari, R. E. (2018). An evaluation of students industrial training courses implementation at higher education. Jurnal Pendidikan Vokasi, 8(3), 258-266. https://doi.org/10.21831/jpv.v8i3.20775

Anamara, M. G. V. (2014). Evaluasi Implementasi Standar PAUD. Jurnal Pendidikan Anak Usia Dini. Jurnal Pendidikan Anak Usia Dini., Vol. 8 edi.

Arikunto, S. (2012). Evaluasi Program Pendidikan. Jakarta: Bumi Aksara.

Ayuningtyas, F., Hartati, S., \& Sumadi, T. (2019). The Impact of Academic Press and Student Teacher Relationship on Childrens Emotional Adjustment. Jurnal Obsesi: Jurnal Pendidikan Anak Usia Dini, 3(1), 91. https:/ / doi.org/10.31004/obsesi.v3i1.148

Fadlillah, M \& Lilif, M. K. (2013). Pendidikan Karakter Anak Usia Dini. Yogyakarta: Ar Ruzz Media.

Hartati, S. (2017). Penyelenggaraan Program PAUD ( Studi Evaluatif Di POS PAUD Kota Jakarta Timur , Provinsi DKI Jakarta ). 12(2), 155-162. https:// doi.org/10.21009/JIV.1202.8

Kemendikbud. (2015). Peraturan Menteri Pendidikan Dan Kebudayaan Republik Indonesia Nomor 146 Tahun 2014 Tentang Kurikulum 2013 Pendidikan Anak Usia Dini.

Lastuti, S., \& Jaedun, A. (2014). Evaluasi pelaksanaan program S1 PGSD di unit program belajar jarak jauh UT DIY. Jurnal Kependidikan: Penelitian Inovasi Pembelajaran, 44(1).

Mahmudi, I. (2011). CIPP: Suatu Model Evaluasi Program Pendidikan. Jurnal At-Ta'dib, Vol. 6, No.

Muyana, S. (2017). Context Input Process Product (CIPP): Model Evaluasi Layanan 
Informasi. Prosiding Seminar Bimbingan Dan Konseling, Vol. 1, No.

Pendidikan, M. (2016). Peraturan menteri pendidikan dan kebudayaan No 146 Tahun 2014 tentang kurikulum 2013 pendidikan anak usia dini. Diakses tanggal.

Pendidikan, M., Kebudayaan, D. A. N., \& Indonesia, R. (2014). PERMENDIKBUD No. 137. 13.

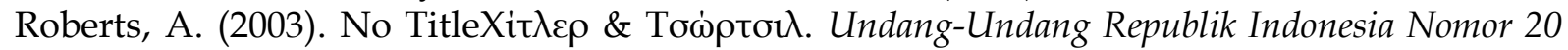
Tahun 2003 Tentang Sistem Pendidikan Nasional Dengan Rahmat Tuhan Yang Maha Esa Presiden Republik Indonesia, (1), 1-26.

Suryana, Dadan \& Fitri, A. R. (2018). Pembelajaran Kurikulum 2013 PAUD Berbasis Pendekatan Saintifik. In Academia.edu.

Suryana, D. (2013). Pengetahuan tentang strategi pembelajaran, sikap, dan motivasi guru. Jurnal Ilmu Pendidikan Universitas Negeri Malang, 19(2).

Suryana, D. (2014a). Dasar-Dasar Pendidikan TK. In Universitas Terbuka. (Ed.), Dasar-Dasar Pendidikan TK. Padang.

Suryana, D. (2014b). Kurikulum Pendidikan Anak Usia Dini Berbasis Perkembangan Anak. Jurnal Pesona Dasar, Vol. 2.

Sutomo. (2014). Manajemen Sekolah. Semarang: Unnes Press.

Tamaya, E. (2017). Prasarana PAUD Dikaji Berdasarkan. Skripsi, (137).

Yaswinda, Y. (2017). Development of a Procedural Model of Science Based on MultisensoryEcology for Early Childhood Education. International Conference of Early Childhood Education (ICECE 2017). Atlantis Press. https:// doi.org/10.2991/icece-16.2017.81

Yaswinda, Y., Yulsyofriend, Y., \& Mayar, F. (2018). Pengembangan Bahan Pembelajaran Sains Berbasis Multisensori Ekologi Bagi Guru Paud Kecamatan Tilatang Kamang Kabupaten Agam. Yaa Bunayya: Jurnal Pendidikan Anak Usia Dini, 2(2), 13-22. 